\title{
Maximizing Organization Performance: The Role of Travel Business in Jakarta?
}

\author{
Ian Nurpatria Suryawan ${ }^{1}$ \\ ${ }^{1}$ Trisakti School of Management \\ Email Address: \\ inp@ @sm.ac.id
}

\begin{abstract}
This research have a purpose to analyze the affect of competitive intensity, dynamic capability, organization slack and organization innovation on organization performance on travel business in Jakarta. The sampling method was carried out by researchers utilizing non-probability sampling with the number of questionnaires distributed randomly to 100 travel business owners. The results of this study show the results of testing 4 (four) hypotheses: competitive intensity has an effect on organization innovation, organizational slack has an effect on organization innovation and; organization innovation has an influence on organization performance and dynamic capability has no influence on organizational innovation. This research has a novelty on competitive intensity, organization slack and organization innovation actually improve organization performance in tourism travel businesses in Jakarta. This study, making policies related to dynamic capability on organizational performance was do not have the ability to seize opportunities and turn organizational resources into more productive.
\end{abstract}

Keywords: organization performance, travel business.

Abstrak: Penelitian ini memiliki tujuan melakukan analisis pengaruh competitive intensity, dynamic capability, organizational slack dan organization innovation terhadap organization performance pada usaha perjalanan wisata di Jakarta. Metode pengambilan sampel dilakukan oleh peneliti memanfaatkan teknik non-probability sampling dengan jumlah kuesioner yang disebarkan secara acak kepada 100 pemilik usaha travel. Hasil penelitian ini menunjukkan hasil pengujian 4 (empat) hipotesis: competitive intensity berpengaruh terhadap organization innovation, organizational slack berpengaruh terhadap organization innovation dan; organization innovation berpengaruh terhadap organization performance dan dynamic capability tidak berpengaruh terhadap organization innovation. Penelitian ini memiliki kebaruan pada competitive intensity, organizational slack dan organization innovation yang benar-benar dapat meningkatkan organization performance pada usaha perjalanan wisata di Jakarta. Dalam penelitian ini, para pemilik usaha terkait dynamic capability terhadap organization performance ternyata tidak mampu menangkap peluang dan mengubah basis sumber daya organisasi menjadi lebih produktif.

Kata Kunci: organization performance, usaha perjalanan wisata. 


\section{INTRODUCTION}

Entering 2022, the travel business has improved in line with the improvement of MSMEs in Indonesia. Also at the same time, adequate planning of the travel business sector requires complete knowledge, so as to maximize the performance of the travel business (Rangel et al., 2020)

The government provides assistance to the MSME's sector through KUR. People's Business Credit (KUR) is one of the government's programs in increasing access to financing for Micro, Small and Medium Enterprises (MSMEs) which are channeled through financial institutions with a guarantee pattern. The purpose of the KUR program is to strengthen business capital capabilities in the context of implementing policies to accelerate real sector development and empower MSMEs.

Travel business activities are very dependent on the assets owned by the companies. Starting in 2022, the realization of KUR is increasing as seen in table 1 data.

Table 1. Realization of KUR Distribution in the Tourism Sector

\begin{tabular}{|c|c|c|c|}
\hline $\begin{array}{c}\text { Accumulated } \\
\text { value of } \\
\text { KUR } \\
\text { Parekraf } \\
\end{array}$ & \multicolumn{2}{|c|}{$\begin{array}{c}2020 \\
\text { (In Rupiah currency) }\end{array}$} & $\begin{array}{c}2021 \\
(* \text { Dec=Temporary data) } \\
\text { (In Rupiah currency) }\end{array}$ \\
\hline January & \multicolumn{2}{|r|}{ 7.833.074.159.696 } & 7.264.789.373.057 \\
\hline February & \multicolumn{2}{|r|}{ 17.391.864.381.889 } & 16.947 .994 .762 .400 \\
\hline March & \multirow{2}{*}{\multicolumn{2}{|c|}{\begin{tabular}{|l}
25.894 .994 .166 .085 \\
28.888 .974 .243 .688
\end{tabular}}} & 28.167 .771 .862 .407 \\
\hline April & & & 38.363 .810 .042 .044 \\
\hline May & \multicolumn{2}{|c|}{30.998 .940 .612 .941} & 45.462 .742 .536 .377 \\
\hline June & \multicolumn{2}{|r|}{35.628 .260 .259 .143} & 55.847 .512 .273 .970 \\
\hline July & \multicolumn{2}{|c|}{42.922 .218 .543 .989} & 64.366 .378 .016 .149 \\
\hline August & \multicolumn{2}{|r|}{49.869 .809 .166 .516} & 77.408 .150 .437 .447 \\
\hline September & \multicolumn{2}{|r|}{59.059 .012 .614 .166} & 90.354 .921 .705 .496 \\
\hline October & \multicolumn{2}{|r|}{68.605 .767 .434 .501} & 102.591 .460 .210 .793 \\
\hline November & \multicolumn{2}{|c|}{80.058 .638 .036 .635} & 115.113 .604 .972 .202 \\
\hline December & \multicolumn{2}{|r|}{81.095 .803 .327 .153} & 120.757 .956 .102 .890 \\
\hline $\begin{array}{l}\text { Realization of } \\
\text { Tourism KUR }\end{array}$ & $\begin{array}{c}\text { Target } \\
\text { (In Rupiah } \\
\text { currency) }\end{array}$ & $\begin{array}{c}\text { Realization } \\
\text { (In Rupiah currency) }\end{array}$ & Description \\
\hline 2019 & & 13.358 .454 .547 .335 & tourism sector \\
\hline 2020 & 13.300 .000 .000 .000 & 81.095 .803 .327 .153 & tourism sector and creative economy \\
\hline 2021 & & 120.757 .956 .102 .890 & $\begin{array}{l}\text { tourism sector and creative economy } \\
\text { (until December } 17,2021 \text { ) }\end{array}$ \\
\hline
\end{tabular}

Source: Kemenparekraf Communication Bureau, 2021

It can be seen in table 1 that the growth rate of KUR Parekraf increased from January to December in 2020 to 2021. The realization of Tourism KUR in 2019 was Rp. 13.358.454.547.335 in the tourism sector. Then in 2020 it is Rp. 81.095.803.327.153 for the tourism and creative economy sectors. Also for 2021 it will increase to Rp. 
120.757.956.102.890. Seeing this, the more optimistic for the growth of economic in the years to come.

The government is moving quickly to help provide incentive assistance to Tourism and Creative Economy Business Actors in a targeted, appropriate and timely manner (Gercep Program). The Gercep Program is divided into: Government Incentive Assistance (BIP), Government Assistance for Tourism Business (BPUP), PEN Film assistance, BBI PEN assistance, reactivation of the tourism industry and facilitation of health workers, CHSE certification.

The government is also working together to take advantage of all the potential to generate and maintain the tourism industry (Geber program). The Geber program is divided into: vaccination program, Lake Toba creative buying program, Indonesia Spice Up the World movement. The government also launched the Gaspol program being to work on all potentials in the tourism sector to open up the widest possible employment opportunities for the community.

In this regard, this study seeks to determine the performance of the travel business owned by tourism business owners in Jakarta.

Competitive intensity can explain the phenomenon of companies facing a competitive environment and the consequences resulting from innovations that have been carried out then can increase organization performance (Marín-Idárraga and Cuartas-Marín, 2019). Furthermore, Idarraga \& Marin states in these competitive conditions, organizations can use their resources and knowledge to avoid risk factors, uncertainty and other factors to improve organizational performance. The study conducted by Marín-Idárraga \& Cuartas-Marín made contribution is competitive intensity and encourage innovation so that it has a positive impact on performance. The study conducted by Marín-Idárraga \& Cuartas-Marín proves that this action has a positive impact on organizational performance.

Dynamic capabilities can be said to be an organization's performance in innovating in a chaotic environment and highly dependent on the resources available to the organization (Babelytė-Labanauskè and Nedzinskas, 2017). Research conducted by (Babelyté-Labanauskè and Nedzinskas, 2017) revealed that there is a positive influence of dynamic capability on organizational innovation performance. All of these things require changes to be something different from before being a service process by an organization called organization innovation (Najmi et al., 2018) so that organization performance is maximized (Turulja and Bajgorić, 2018). The study conducted by (Najmi et al., 2018) proves, First, dynamic capability as a mediating variable in the relationship between knowledge management and organizational performance, shows that knowledge management can improve organizational performance, if the mediated dynamic capability is also higher. Second, dynamic capability as a mediation in the relationship between strategic leadership and organizational performance shows that higher strategic leadership will lead to an increase in organizational performance, if mediated dynamic capability is also higher. 
Organization slack means the company's performance in survival and can adapt to changes that occur in the company's environment so that it has a positive impact so that it can improve organization performance (Marín-Idárraga and Cuartas-Marín, 2019).

Organization innovation is an organization that has experience with what has been done before, so that it can provide increased organization performance because it already has valuable experience so that it can have a mission and vision (Kumaravel, 2018). The findings of the research conducted by Kumaravel indicate that there is a strong positive impact on knowledge management. Knowledge management is a determinant of success in organizational performance. Kumaravel suggests improving knowledge management in organizations to improve organizational performance. The findings of the research conducted by Kumaravel are supported by Marín-Idárraga \& Cuartas-Marín. The study by MarínIdárraga \& Cuartas-Marín made contribution is intense competition, innovation is necessary because it can improve performance. The results of research conducted by Marín-Idárraga \& Cuartas-Marín prove that there is a relationship between innovation and performance.

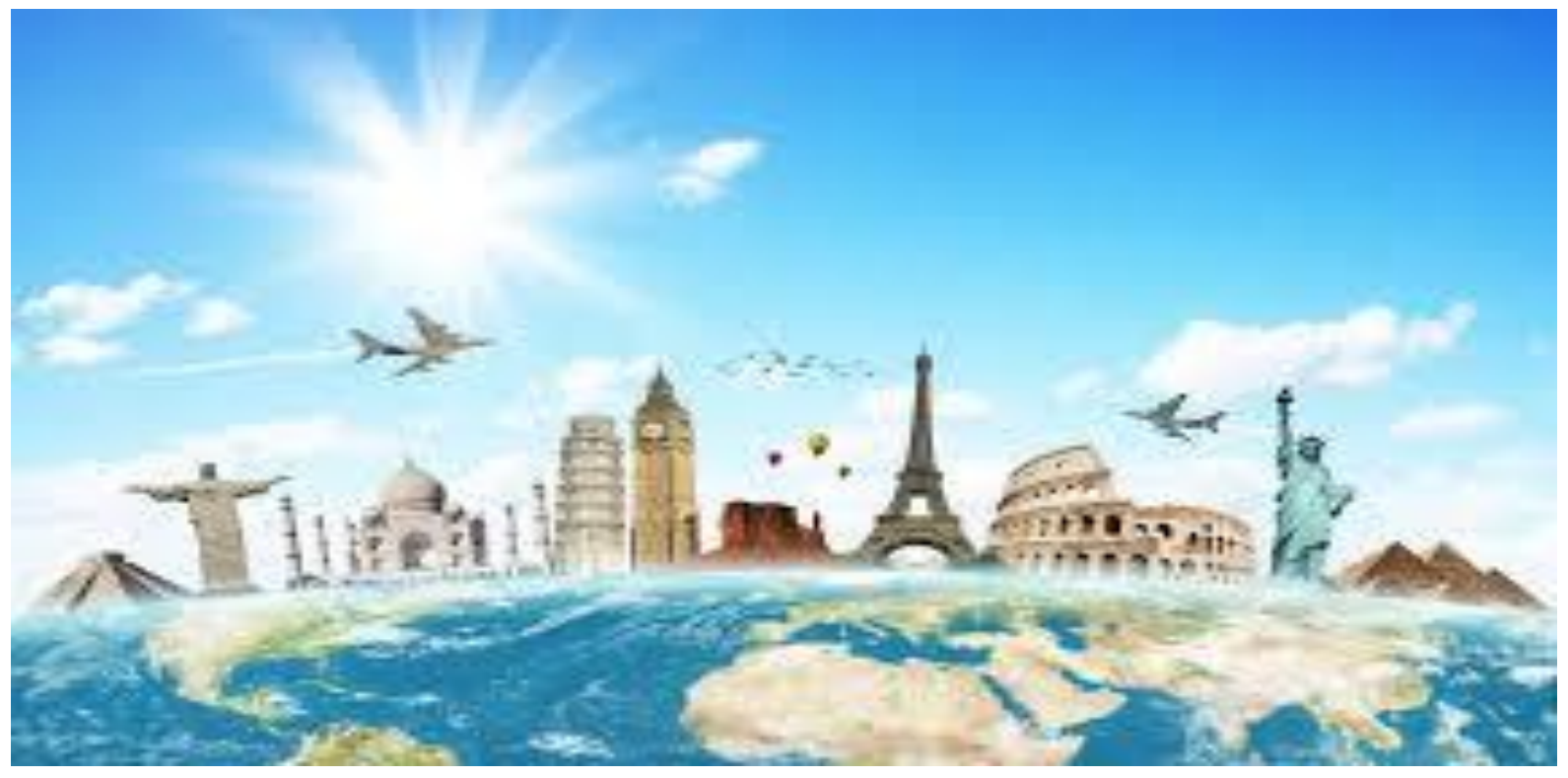

Figure 1. Travel business

Source: https://hinyong.com/usaha-perjalanan-wisata/

The world is so beautiful (see Figure 1 and Figure 2), so it is necessary for everyone to travel to please everyone. This is an opportunity for tourism business owners to maximize their business performance in order to satisfy the needs of travel agents.

Research Purposes. This research was conducted to study: (1) The positive effect of competitive intensity on organization innovation on travel business in Jakarta. (2) The positive 
effect of dynamic capability on organization innovation on travel business in Jakarta. (3) The positive effect of organizational slack on organization innovation on travel business in Jakarta. (4) The positive influence of organization innovation on organization performance on travel business in Jakarta.

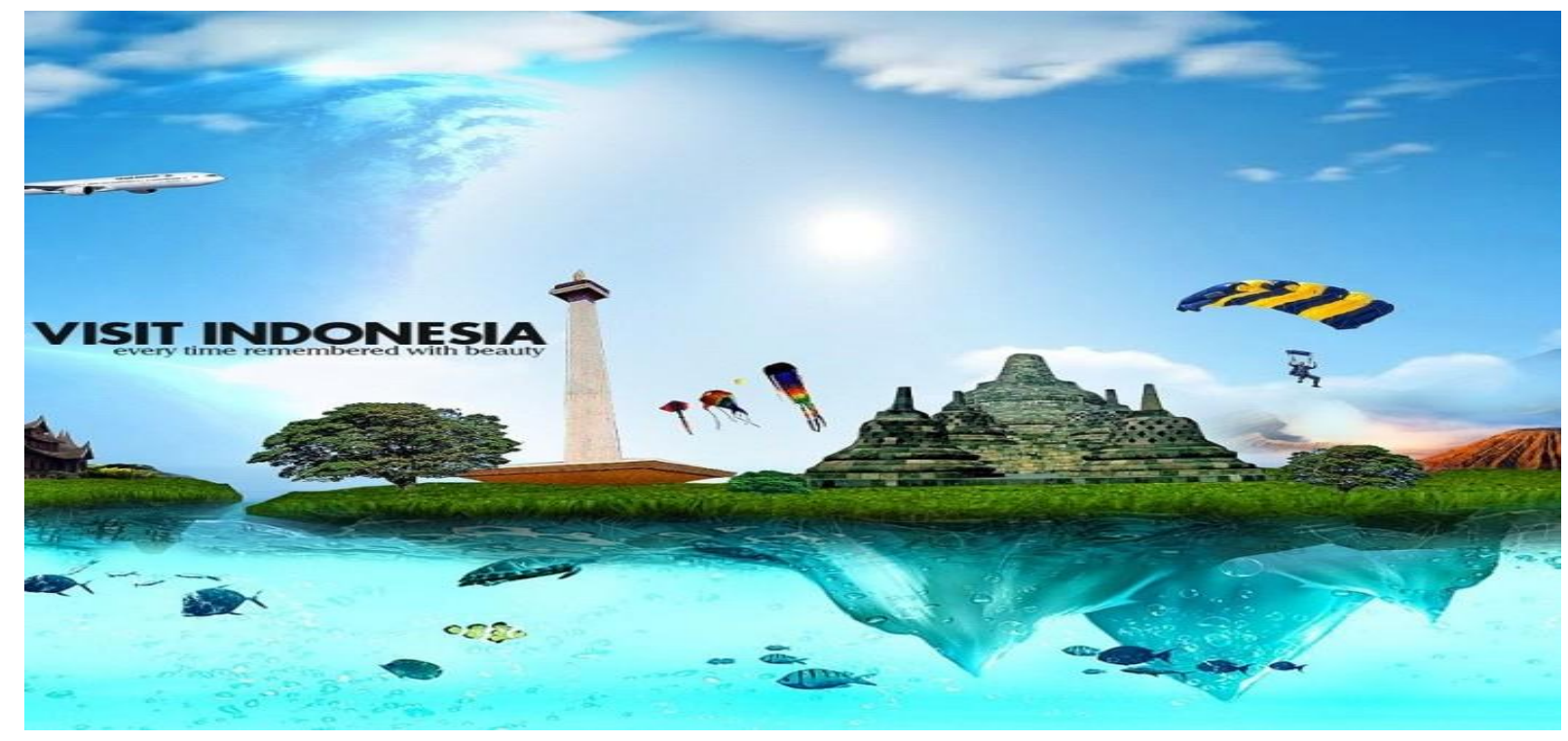

Figure 2. Travel business

Source : https://www.kelase.com/institusi/73310-keahlianganda/kelas/detail/3232-Usaha-Perjalanan-Wisata

In connection (Figure 2) with the purpose of the research objective, this research was only conducted on the owners of travel business in Jakarta, Indonesia.

\section{THEORETICAL REVIEW}

Competitive intensity has an understanding of the organization using all its resources in facing highly competitive (Marín-Idárraga and Cuartas-Marín, 2019). (East et al., 2017) have made direct observations of the pattern of visits to a particular tourist attraction, so that most visitors will always do it repeatedly. Furthermore, (Marín-Idárraga and Cuartas-Marín, 2019) divides competitive intensity into 3 (three) indicators:

Management is trying to increase price competition. The setting of a higher price strategy than competitors applies to products that have brands in the market. Only the product or service has something special when it comes to implementing this strategy.

There is a competitive effect on the company's operational sector. Challenges are common in every industry where progress in infrastructure and communication is the result of changes that occur and certainly have an impact on every aspect of life, be it cultural or economic. 
Only through very tight competition where organizations are required to have a good strategy to create a competitive advantage, organizations in their efforts to create competitive advantage must carry out competitor analysis on an ongoing basis (Stoilkovska et al., 2015).

There are efforts to increase competition in the face of competitors. Every organization that has a competitive advantage, for every organization is expected to adapt quickly to its market environment. For organizations that are facing increasing competition in their markets, but fail to adopt and implement competitive advantage strategies to face the competition, their performance is likely to deteriorate.

Based on various existing theories, the following hypotheses can be formulated:

H1: Competitive Intensity affects Organization Innovation.

Dynamic capabilities can be said to be an organization's performance in innovating in a chaotic environment and highly dependent on the resources available to the organization (Babelyte-Labanauskè and Nedzinskas, 2017). Meanwhile, dynamic capability is defined by (Giniuniene and Jurksiene, 2015) as the company's performance in integrating, building and reconfiguring environmental competence in and around the company in the face of sudden changes. (Holey et al., 2008) defines dynamic capabilities as the ability to search for and find completely new production materials, make them classified, make various special innovations and classify them into determining market positioning for the products they have created. Henceforth, (Babelytė-Labanauskè and Nedzinskas, 2017) group dynamic capability into 3 (three) indicators, namely:

Sense. Organizational elements that include the dimensions of external and internal environmental assessment (as seen from the performance of the institution) in terms of readiness to cooperate with external parties using intellectual abilities and technically partnering with external parties to identify new solutions based on research and development results.

Seize. The components of the organization's strategic management which include strategic planning, fixing the organization, various facilities owned by the organization are part of the organizational compatibility that affects the effectiveness of the organization's strategic management. It shows the status of the workings of the company, collaborative work style, the desire and loyalty of every employee of the company, make important decisions, find ways to resolve conflicts, and professional specializations that make up a professional work team.

Reconfigure. Successful organizational performance can be seen in ability to lead the company professionally and willing and able to apply adequately governance to bring about change. Reconfiguration of resources always follows the environment dynamics in building the basic capabilities of the organization's resources. 
Based on various existing theories, the following hypotheses can be formulated:

H2: Dynamic Capability affects Organization Innovation.

Organization slack means the company's performance in survival and can adapt to changes that occur in the company's environment so that it has a positive impact so that it can improve organization performance (Marín-Idárraga and Cuartas-Marín, 2019) Henceforth, (MarínIdárraga and Cuartas-Marín, 2019) grouped organizational slack into 3 (three) indicators, namely:

The company uses its capabilities in making strategic decisions. The company is able to get economic benefits above the profits that can be achieved by competitors in the market in the same industry. In this case, the company has a competitive advantage, namely having the ability to understand changing market structures and being able to choose an effective strategy. The company's ability to determine a competitive strategy is the right step to have a competitive advantage, so that consumers become interested in the products offered, strengthen market segments, and can survive the competitive pressures faced by the company.

The company has the ability to make long-term plans. It can be seen that the plan is drawn up using all the reasoning abilities that are carried out to achieve the company's goals. The company has plans to perform management functions and reward performance. For that, companies need a leader who can do the job required by the company and able to lead the company well. Planning must be done using performance appraisals for each employee for the sake of the progress of the company can be redesigned to produce good and useful production and services.

The company has administrative discretion to make new long-term plans. Administrative discretion is the process of organizing work to achieve a goal that has been set by the company. Individuals who carry out work to achieve these goals are the main problems of management. So, in determining policies to implementing planning, there are several things, namely: authorization, parties who make decisions, and factors in decision making.

Based on various existing theories, the following hypotheses can be formulated:

H3: Organizational Slack affects Organization Innovation.

Organizational innovation states something about every change made to the work of innovating is something new in improving service to customers (Ganguly et al., 2019). Organization innovation is an organization that has experience with what has been done before, so that it can provide increased organization performance because it already has valuable experience so that it can have a mission and vision (Kumaravel, 2018). Innovation in travel business is very important in terms of business continuity, competitiveness and sales growth (Orfila-Sintes and Mattsson, 2014); (Harrington and Ottenbacher, 2013); (Eide et al., 2017). Henceforth, (Ganguly et al., 2019) groups organization innovation into 4 (four) indicators, namely: 
Innovation capability. Innovation capability is the main factor to improve organizational performance, business survival, growth and competitive advantage. An organization's innovation capability is the knowledge and competence needed to create new products and/or technologies and improve the capabilities of existing products or services. Innovation capability can give companies a sustainable, non-modifiable competitive advantage that is closely tied to experimental and experience gains. Innovation is a strength for the company and through the innovation process, the company continues to make changes for the better which not only leads to the use of existing resources but also seeks resources that are not owned by other organizations and are very valuable.

Tacit knowledge sharing. Tacit knowledge can be explained into explicit and tacit knowledge. Explicit knowledge is found in documentation and everyone knows that it is knowledge that comes from experience and much is not documented. Although it is difficult to explain scientifically, tacit knowledge is a source of knowledge owned by organizations. There is a lot of knowledge related to work that is "invisible" so knowledge sharing makes it even more important for maximizing company performance.

Social capital relational. Social capital is a way to take advantage of the valuable resources contained in relational bonds. Social capital is found in friendships and interactions with the community. Social relational capital is an important factor in making various changes and innovations within the company in order to achieve the mission and vision that has been set by the company's organizational management.

Social capital cognitive. Cognitive social capital always involves understanding in togetherness among individuals by using language codes between them, building trust and shared narratives. Each individual can recognize and understand then exchange experiences between them. Within the company there is a vision and mission that becomes a common reference among individuals by integrating each experience.

Organization performance is a predetermined goal setting by the organization by innovating in making adjustments to conditions in an environment that changes at any time (Turulja and Bajgorić, 2018). Henceforth, (Turulja \& Bajgorić, 2018) grouped organization performance into 3 (three) indicators, namely:

Organizations seek to increase return on investment. Carry out cost efficiency in the company. Every company makes efficient use of costs in order to successfully increase the return on investment.

The organization seeks to increase sales and profitability. Sales volume is very important and decisive for the company in achieving the company's goals, namely earning profits to maintain the survival of the company. Usually, sales volume is the result of sales expressed in the form of numbers and an analysis of the progress of sales results. Sales volume it can be said that the work done by the company to meet customer needs.

Organizations are successful in cultivating customers. Organizational management must develop a very strategic plan to focus on the needs and desires of consumers, so that it can generate sales that are very profitable for the company and are sustainable in the future. 
Based on various existing theories, the following hypotheses can be formulated:

H4: Organization Innovation affects Organization Performance.

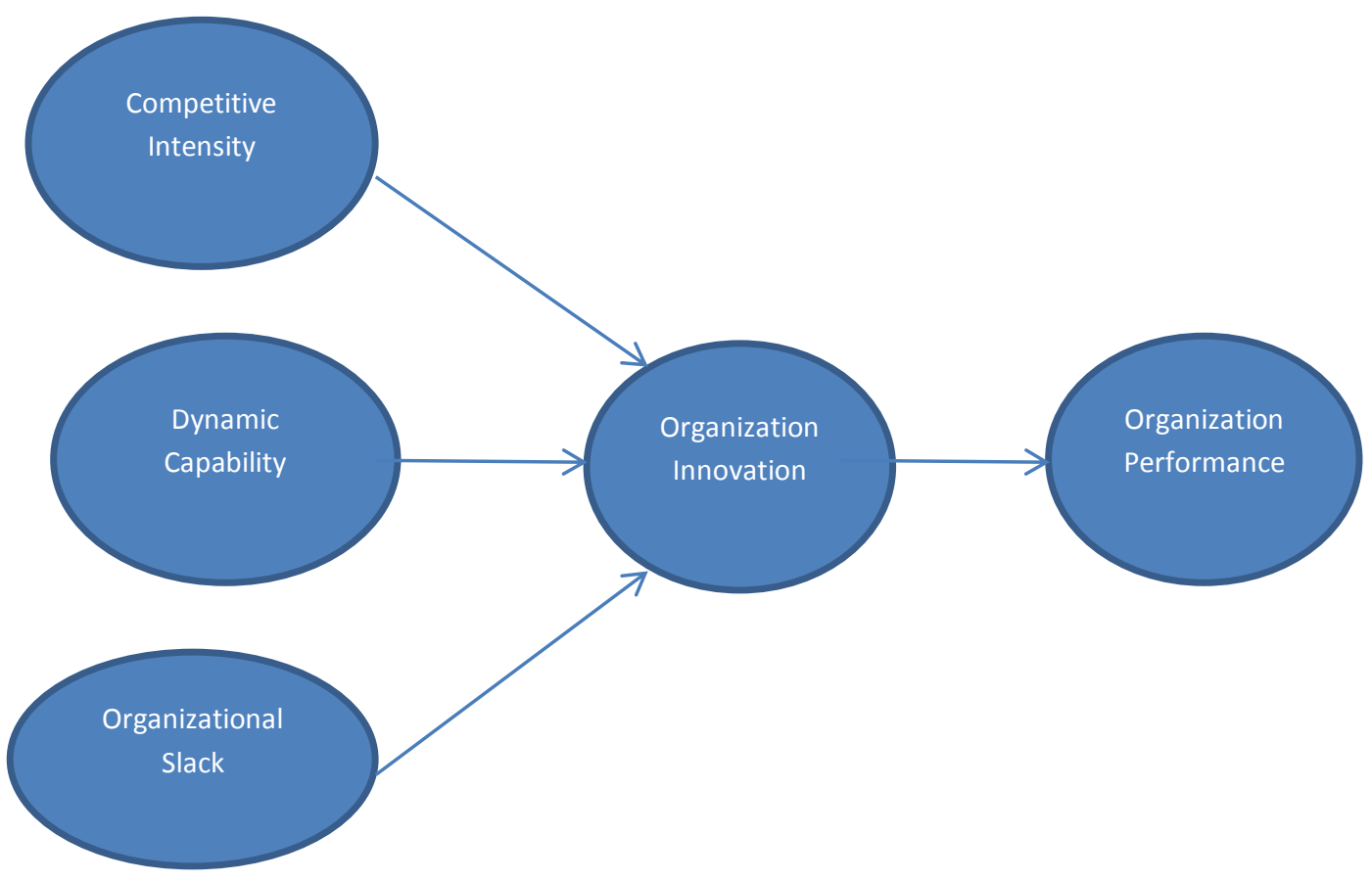

Figure 3. Research Model.

Source: Research Model, 2022

\section{METHODS}

The sampling method was carried out by researchers utilizing non-probability sampling with the number of questionnaires distributed to 100 travel business owners randomly from all over Jakarta. The samples taken by the researchers were divided into 49 male and 51 female business travel owners. The age of the travel business owners is from 25 to 50 years old. The respondents after filling out a questionnaire containing questions that have been provided by the researcher, then the results of the questionnaire are processed using the Partial Least Square software tool. 
Table 2. Variables and Indicators

\begin{tabular}{|c|c|c|c|c|c|}
\hline & Variable & Definition & Indicator & Scale & Source \\
\hline 1. & Competitive Intensity & $\begin{array}{c}\text { Competitive intensity can } \\
\text { explain the phenomenon of } \\
\text { companies facing a } \\
\text { competitive environment and } \\
\text { the consequences resulting } \\
\text { from innovations that have } \\
\text { been carried out then can } \\
\text { increase organization } \\
\text { performance. }\end{array}$ & $\begin{array}{l}\text { 1. Management seeks to } \\
\text { increase price } \\
\text { competition (CI1). } \\
\text { 2. There is a competitive } \\
\text { effect on the company's } \\
\text { operational sector (CI2). } \\
\text { 3. There are efforts to } \\
\text { increase competition in } \\
\text { the face of competitors } \\
\text { (CI3). }\end{array}$ & Ordinal & $\begin{array}{c}\text { (Marín- } \\
\text { Idárraga and } \\
\text { Cuartas- } \\
\text { Marín, 2019) }\end{array}$ \\
\hline 2. & Dynamic Capability & $\begin{array}{l}\text { Dynamic capabilities can be } \\
\text { said to be an organization's } \\
\text { performance in innovating in a } \\
\text { chaotic environment and } \\
\text { highly dependent on the } \\
\text { resources available to the } \\
\text { organization. }\end{array}$ & $\begin{array}{l}\text { 1. We are ready to } \\
\text { improve analytical skills } \\
\text { (Sense) (DC1). } \\
\text { 2. We make strategic } \\
\text { planning for the } \\
\text { organization (Seize) } \\
\text { (DC2). } \\
\text { 3. We update the } \\
\text { organization's resources } \\
\text { (Reconfigure) (DC3). }\end{array}$ & Ordinal & $\begin{array}{l}\text { (Babelytè- } \\
\text { Labanauskè } \\
\text { and } \\
\text { Nedzinskas, } \\
\text { 2017) }\end{array}$ \\
\hline 3. & Organizational Slack & $\begin{array}{l}\text { Organizational slack is all } \\
\text { resources in the form of } \\
\text { wealth from the organization } \\
\text { needed by each existing } \\
\text { division and cooperate with } \\
\text { each other in completing every } \\
\text { work that has been set by } \\
\text { management in order to } \\
\text { achieve the mission and } \\
\text { vision. }\end{array}$ & $\begin{array}{l}\text { 1. The company uses its } \\
\text { capabilities in making } \\
\text { strategic decisions } \\
\text { (ORS1). } \\
\text { 2. The company has the } \\
\text { ability to make long- } \\
\text { term plans (ORS2). } \\
\text { 3. The company has } \\
\text { administrative } \\
\text { discretion to make new } \\
\text { long-term plans } \\
\text { (ORS3). }\end{array}$ & Ordinal & $\begin{array}{c}\text { (Marín- } \\
\text { Idárraga and } \\
\text { Cuartas- } \\
\text { Marín, 2019) }\end{array}$ \\
\hline 4. & $\begin{array}{l}\text { Organization } \\
\text { Innovation }\end{array}$ & $\begin{array}{l}\text { Organizational innovation } \\
\text { states something about every } \\
\text { change made to the work of } \\
\text { innovating is something new } \\
\text { in improving service to } \\
\text { customers. }\end{array}$ & $\begin{array}{l}\text { 1. In the last three years, } \\
\text { the organization I work } \\
\text { for has been very } \\
\text { creative (Innovation } \\
\text { Capability) (OI1). } \\
\text { 2. Understanding other } \\
\text { people's thoughts well } \\
\text { is repeating what } \\
\text { someone said (Tacit } \\
\text { Knowledge Sharing) } \\
\text { (OI2). } \\
\text { 3. We work to show } \\
\text { extraordinary integrity } \\
\text { (Social Capital } \\
\text { Relational) (OI3). } \\
\text { 4. We are committed to }\end{array}$ & Ordinal & $\begin{array}{c}\text { (Ganguly et } \\
\text { al., 2019) }\end{array}$ \\
\hline
\end{tabular}


Suryawan: Maximizing Organization Performance:...

\begin{tabular}{|c|c|c|c|c|c|}
\hline & & & $\begin{array}{l}\text { advancing the company } \\
\text { (Social Capital } \\
\text { Cognitive) (OI4). }\end{array}$ & & \\
\hline 5. & $\begin{array}{l}\text { Organization } \\
\text { Performance }\end{array}$ & $\begin{array}{l}\text { Organization performance is a } \\
\text { predetermined goal setting by } \\
\text { the organization by innovating } \\
\text { to survive in a dynamic } \\
\text { environment. }\end{array}$ & $\begin{array}{l}\text { 1. We have increased our } \\
\text { return on investment, } \\
\text { over the last few years } \\
\text { (OP1). } \\
\text { 2. We have increased the } \\
\text { organization's sales in } \\
\text { recent years (OP2). } \\
\text { 3. Over the past few years, } \\
\text { we have successfully } \\
\text { cultivated customers } \\
\text { (OP3). }\end{array}$ & Ordinal & $\begin{array}{l}\text { (Turulja and } \\
\text { Bajgorić, } \\
\text { 2018) }\end{array}$ \\
\hline
\end{tabular}

Source: Results of data processing, 2022 


\section{RESULTS}

For the next are the results of data processing that has been carried out by researchers.

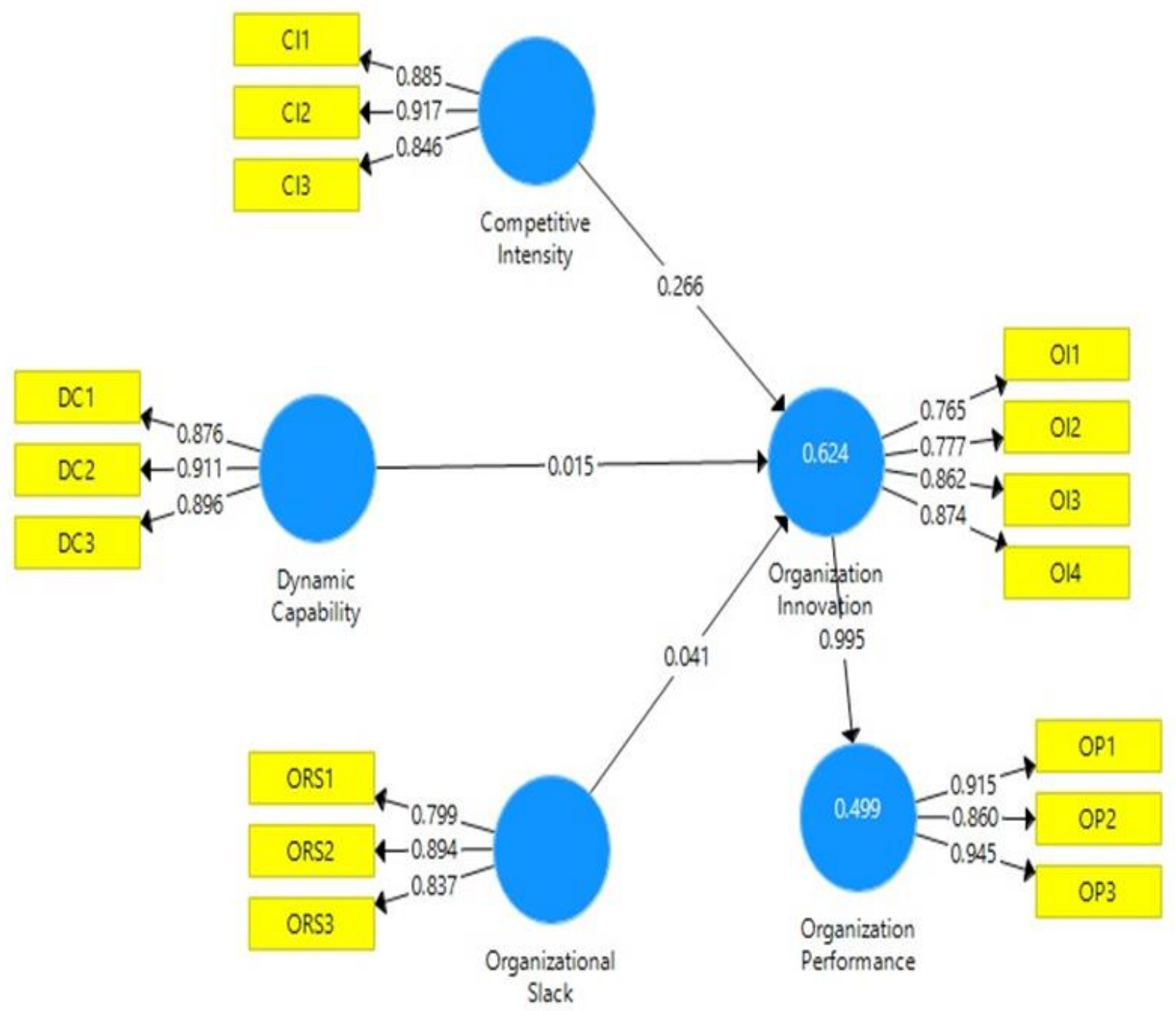

Figure 4. Outer Model

Source: Results of data processing, 2022

Outer Model. In the outer model, the results obtained are CI1 of 0.885 , CI2 of 0.917 , CI3 of 0.846, DC1 of 0.876, DC2 of 0.911, DC 3 of 0.896 , ORS 1 of 0.799, ORS2 of 0.894 , ORS3 of 0.837 , OI 1 of 0.765 , OI 2 of 0.777 , OI 3 of 0.862 , OI 4 of 0.874 , OP1 of 0.915, OP 2 of 0.860 , OP3 of 0.945 . 
Table 3. Evaluation Model in Measurement

\begin{tabular}{|c|c|c|}
\hline \multicolumn{3}{|c|}{ Constructs and items } \\
\hline \multicolumn{3}{|c|}{ Competitive Intensity $(A V E=0.780, C R=0.914)$} \\
\hline CI1 & Management seeks to increase price competition. & 0.885 \\
\hline $\mathrm{CI} 2$ & There is a competitive effect on the company's operational sector. & 0.917 \\
\hline $\mathrm{CI} 3$ & There are efforts to increase competition in the face of competitors. & 0.846 \\
\hline \multicolumn{3}{|c|}{ Dynamic Capability $(A V E=0.800, C R=0.923)$} \\
\hline DC1 & We are ready to improve analytical skills (Sense). & 0.876 \\
\hline DC2 & We make strategic planning for the organization (Seize). & 0.911 \\
\hline DC3 & We update the organization's resources (Reconfigure). & 0.896 \\
\hline \multicolumn{3}{|c|}{ Organizational Slack $(A V E=0.713, C R=0.881)$} \\
\hline ORS1 & The company uses its capabilities in making strategic decisions. & 0.799 \\
\hline ORS2 & The company has the ability to make long-term plans. & 0.894 \\
\hline ORS3 & The company has administrative discretion to make new long-term plans. & 0.837 \\
\hline \multicolumn{3}{|c|}{ Organization Innovation $(A V E=0.674, C R=0.892)$} \\
\hline OI1 & $\begin{array}{l}\text { In the last three years, the organization I work for has been very creative } \\
\text { (Innovation Capability). }\end{array}$ & 0.765 \\
\hline OI2 & $\begin{array}{l}\text { Understanding other people's thoughts well is repeating what someone said (Tacit } \\
\text { Knowledge Sharing). }\end{array}$ & 0.777 \\
\hline OI3 & We work to show extraordinary integrity (Social Capital Relational) & 0.862 \\
\hline OI4 & We are committed to advancing the company (Social Capital Cognitive). & 0.874 \\
\hline \multicolumn{3}{|c|}{ Organization Performance $(A V E=0.823, C R=0.933)$} \\
\hline OP1 & We have increased our return on investment, over the last few years. & 0.915 \\
\hline OP2 & We have increased the organization's sales in recent years. & 0.860 \\
\hline OP3 & Over the past few years, we have successfully cultivated customers & 0.945 \\
\hline
\end{tabular}

Evaluation Model in Measurement. This analysis, discusses about validity and reliability results. For the indicator to be declared valid, the outer loading must be greater than 0.50 and have $\rho$ - value is smaller than 0.05 . Meanwhile, the condition for a variable to be said to be reliable is if the variable passes the internal consistency reliability test with a CR value is bigger than 0.70 and is smaller than 0.95 . The results of data processing are shown in table 3 which shows the results of the benchmark in carrying out the measurement is valid. The results of AVE value is look in the range of 0.674 to 0.823 . For the number of outer loadings, it is at 0.765 until the number is 0.945 . The value of outer loadings seen from the range of 0.4 to 0.7 can be said to be maintained as long as it can increase the AVE value. (Latan \& Noonan, 2017) explain in detail and clearly that the reliability test can be carried out by researchers by calculating the $\mathrm{CR}$. It can be said to be successful and fulfill the requirements if the calculation results show that the CR value has minimum of 0.7 (Hair, 2015). 
Table 4. Cronbach Alpha

\begin{tabular}{l|c}
\hline & Cronbach's Alpha \\
\hline Competitive Intensity & 0.859 \\
\hline Dynamic Capability & 0.875 \\
\hline Organization Innovation & 0.838 \\
\hline Organization Performance & 0.892 \\
\hline Organizational Slack & 0.799 \\
\hline
\end{tabular}

Source: Results of data processing, 2022

Cronbach Alpha. The Cronbach Alpha test is said to be valid if the numbers that have been calculated by the researcher are seen in the cronbach alpha on the variable is bigger than 0.6. The CR test was strengthened by using the Cronbach alpha value. Each variable can be stated by the researcher in the form of a reliable statement if the Cronbach alpha number is bigger than 0.7 (Hair, 2015). Based on table 4, it can be stated by the researcher that the Cronbach alpha value for each variable that has been seen is bigger than 0.7. So, the results of the calculations have shown and it can be analyzed that each variable has requirements of the Cronbach alpha, and then has a high level of reliability in each variable.

Table 5. Fornell Larcker Criterion

\begin{tabular}{c|c|c|c|c|c}
\hline & CI & DC & OI & OP & ORS \\
\hline CI & 0.833 & & & & \\
\hline DC & 0.795 & 0.895 & & & \\
\hline OI & 0.771 & 0.684 & 0.821 & & \\
\hline OP & 0.749 & 0.645 & 0.706 & 0.907 & 0.844 \\
\hline ORS & 0.674 & 0.668 & 0.633 & 0.593 & \\
\hline
\end{tabular}

Source: Results of data processing, 2022

Fornell Larcker Criterion. A variable can be declared valid by the researcher by comparing the AVE root value with the correlation in the variables. The AVE root is owned must be more visible than the correlation in the variables. Fornell Larcker Criterion is compare the square root value of the AVE on each variable in a correlation with other variables in the research model (Hair, 2015). The square root by the AVE for each variable is bigger than the correlation between the variables and other variables, it means that the research model has suitable discriminant validity (Latan and Noonan, 2017).

Table 6. $\mathrm{R}^{2}$ Evaluation

\begin{tabular}{l|c}
\hline & R Square \\
\hline Organization Innovation & 0.624 \\
\hline Organization Performance & 0.499 \\
\hline Source Resuls of
\end{tabular}

Source: Results of data processing, 2022 
R Square Evaluation. As we can see together in table 6, which is very visible for the $\mathrm{R}$ Square value for the organizational innovation variable which is calculated at 0.624.This figure shows the percentage of organization innovation which is calculated at 62.4 percent. So, the R Square of the variable organization performance is 0.499 . This figure shows the percentage of organization performance which is calculated at 49.9 percent.

Table 7. Hypothesis Test Results

\begin{tabular}{l|c|c|c}
\hline Hypothesis & T-Statistics & P-Values & Decision \\
\hline $\mathrm{H}_{1}:$ Competitive Intensity affects Organization Innovation & 3.834 & 0.000 & Supported \\
\hline $\mathrm{H}_{2}:$ Dynamic Capability affects Organization Innovation & 0.946 & 0.344 & Not supported \\
\hline $\mathrm{H}_{3}:$ Organizational Slack affects Organization Innovation & 1.977 & 0.049 & Supported \\
\hline $\mathrm{H}_{4}:$ Organization Innovation affects Organization Performance & 12.778 & 0.000 & Supported \\
\hline
\end{tabular}

Source: Results of data processing, 2022

Hypothesis Test Results. As seen in table 7, it can be seen that of the four hypotheses proposed in this research is : hypothesis 1, hypothesis 3 and hypothesis 4 can be accepted because each of the effects shown has a value of $\rho$-value is smaller than 0.05 , which consists of hypothesis 1: competitive intensity affects organization innovation, hypothesis 3: organizational slack affects organization innovation and hypothesis 4: organization innovation affects organization performance, but hypothesis 2 has no effect because it has $\rho$ value is bigger than 0.05 , i.e. Hypothesis 2: dynamic capability no affects organization innovation

\section{DISCUSSION}

The results of the first hypothesis $\left(\mathrm{H}_{1}\right)$ that competitive intensity has an effect on organization innovation are supported. Better competitive intensity can have an impact on increasing organization innovation. This first hypothesis is in accordance with the theory from (Marín-Idárraga and Cuartas-Marín, 2019) which states that competitive intensity can explain the phenomenon of companies facing a competitive environment and the consequences resulting from innovations that have been carried out then can increase organization performance. In line with (East et al., 2017) which states that most visitors will always visit a particular tourist attraction repeatedly. Tourists in Jakarta can take advantage of the KUR program provided by the government to make innovations by improving the service facilities provided for tourists. The first hypothesis is supported by research conducted by MarínIdárraga \& Cuartas-Marín that there is a contribution of competitive intensity and encourage innovation so that it has a positive impact on performance.

For the results of testing the second hypothesis $\left(\mathrm{H}_{2}\right)$ dynamic capability has an effect on organization innovation is not supported. Improved dynamic capability does not increase organization innovation. This second hypothesis is not in accordance with the theory of (Babelytė-Labanauskè and Nedzinskas, 2017) which states dynamic capabilities can be said to be an organization's performance in innovating in a chaotic environment and highly dependent 
on the resources available to the organization. And it is not in accordance with the theory of (Giniuniene and Jurksiene, 2015) which states dynamic capability as the company's performance in integrating, building and reconfiguring environmental competence in and around the company in the face of sudden changes, also not in accordance with (Holey et al., 2008) defines daynamic capability as the ability to make companies make improvements with innovation theory, do things in more detail, make changes for the better and classify them into segments based on existing customers and learning. The second hypothesis does not support the research conducted by Babelytė-Labanauske \& Nedzinskas, Giniuniene \& Jurksiene and Holey which reveals that there is a positive influence of dynamic capability on organizational innovation performance.

Then, for the results of the third hypothesis $\left(\mathrm{H}_{3}\right)$ is organizational slack has effect on organization innovation is supported. Better organizational slack can lead to an increase in organization innovation. This is in accordance with the theory of (Marín-Idárraga and Cuartas-Marín, 2019) which states that organization slack means the company's performance in survival and can adapt to changes that occur in the company's environment so that it has a positive impact so that it can improve organization performance. The third hypothesis proves the research conducted by Marín-Idárraga \& Cuartas-Marín that there is a positive relationship between organizational slack and organizational innovation.Also, the fourth hypothesis $\left(\mathrm{H}_{4}\right)$ is organization innovation effect on organization performance are supported. Organization innovation is getting better, so it has an impact on increasing organization performance. This is in accordance with the theory from (Orfila-Sintes and Mattsson, 2014); (Harrington and Ottenbacher, 2013); and (Eide et al., 2017) that innovation in travel business is very important in terms of business continuity, competitiveness and sales growth and also theory from (Ganguly et al., 2019) that is organizational innovation states something about every change made to the work of innovating is something new in improving service to customers. (Kumaravel, 2018) says organization innovation is an organization that has experience with what has been done before, so that it can provide increased organization performance because it already has valuable experience so that it can have a mission and vision.The theory from (Turulja and Bajgorić, 2018) which states that organizational performance is a predetermined goal setting by the organization by innovating to survive in a dynamic environment.

\section{CONCLUSION}

The conclusion of this study provides knowledge for travel business practitioners in DKI Jakarta to increase competitive intensity to accelerate business development, adopt developing existing products or creating new products (innovation), making the supply chain smooth, setting prices appropriately based on the segments that have been created and determined by the company management so that it is successful as seen from the achievement of the mission and vision that has been set at the moment. The state of the organizational environment is unstable (organizational slack). Travel business owners can take advantage of the KUR program to make service innovations for tour guides so that tours become more 
attractive to tourists because the government is moving quickly to help provide incentive assistance to Tourism and Creative Economy Business Actors in a targeted, appropriate and timely manner (Gercep Program) and also working together to take advantage of all the potential to generate and maintain the tourism industry (Geber program) and launched the Gaspol program being to work on all potentials in the tourism sector to open up the widest possible employment opportunities for the community.

Limitations and Suggestions for Future Research. Future research can be carried out on other types of service businesses and in other research locations to prove whether the four hypotheses can affect all or some variables in the end have no effect on organizational performance. Further researchers can also add a variable to the use of tourism-specific KUR as a factor in increasing the success of the travel business.

\section{REFERENCES}

Babelytė-Labanauskè, K., and Nedzinskas, Š. (2017). Dynamic capabilities and their impact on research organizations' R\&D and innovation performance. Journal of Modelling in Management, 12(4), 603-630. https://doi.org/10.1108/JM2-05-2015-0025.

East, Duncan, Osborne, P., Kemp, S. and Woodfine, T. (2017). Combining GPS \& survey data improves understanding of visitor behaviour. Tourism Management, 61, 307-320. https://doi.org/10.1016/j.tourman.2017.02.021.

Eide, Dorthe, Fuglsang, Lars, and Sundbo, Jon (2017). Management challenges with the maintenance of tourism experience concept innovations: Toward a new research agenda. Tourism Management, 63, 452-463. https://doi.org/10.1016/j.tourman.2017.06.029.

Ganguly, A., Talukdar, A., and Chatterjee, D. (2019). Evaluating the role of social capital, tacit knowledge sharing, knowledge quality and reciprocity in determining innovation capability of an organization. In Journal of Knowledge Management (Vol. 23, Issue 6). https://doi.org/10.1108/JKM-03-2018-0190.

Giniuniene, J., and Jurksiene, L. (2015). Dynamic Capabilities, Innovation and Organizational Learning: Interrelations and Impact on Firm Performance. Procedia - Social and Behavioral Sciences, 213(09), 985-991. https://doi.org/10.1016/j.sbspro.2015.11.515.

Hair, Jr, J. F. (2015). Essentials of business research methods. In Essentials of Business Research Methods.

Harrington, R.J. and Ottenbacher, M.C (2013). Managing the culinary innovation process: the case of new product development. Journal of Culinary Science and Technology, 11(1), 4-18. https://doi.org/10.1080/15428052.2012.754724.

https://hinyong.com/usaha-perjalanan-wisata/ (accessed on January 5, 2022).

https://www.kelase.com/institusi/73310-keahlianganda/kelas/detail/3232-Usaha-Perjalanan-

Wisata (accessed on January 5, 2022).

Hooley, G. J., N. Piercy, and B. Nicoulaud. (2008). Marketing strategy and competitive positioning. London: FT Prentice Hall

Kemenparekraf Communication Bureau (2021). Realization of KUR distribution in the 
tourism sector

Kumaravel, V. (2018). Assessment of Knowledge Management Practices in Higher Educational Institutions in India: A Structural Equation Modeling Approach. International Journal of Educational Sciences, 20(1-3), 120-136. https://doi.org/10.31901/24566322.2018/20.1-3.15.

Latan, H., and Noonan, R. (2017). Partial least squares path modeling: Basic concepts, methodological issues and applications. In Partial Least Squares Path Modeling: Basic Concepts, Methodological Issues and Applications. Springer International Publishing.

Marín-Idárraga, D. A., and Cuartas-Marín, J. C. (2019). Relationship between innovation and performance: Impact of competitive intensity and the organizational slack. RAE Revista de Administracao de Empresas, 59(2), 95-107. https://doi.org/10.1590/S0034759020190203.

Najmi, K., Kadir, A. R., and Kadir, M. I. A. (2018). Mediation effect of dynamic capability in the relationship between knowledge management and strategic leadership on organizational performance accountability. International Journal of Law and Management, 60(2), 517-529. https://doi.org/10.1108/IJLMA-01-2017-0004.

Rangel, M. C. R., Rivero, M. S., and Hernández, J. R. (2020). A spatial analysis of intensity in tourism accommodation: An application for extremadura (Spain). Economies, 8(2). https://doi.org/10.3390/ECONOMIES8020028.

Stoilkovska, A., Ristovska, N. and Gramatnikovski, S. (2015). Innovative business models a factor for competitive advantage of the companies. UTMS Journal of Economics, 6(1), 135-146.

Turulja, L., and Bajgorić, N. (2018). Knowing Means Existing: Organizational Learning Dimensions and Knowledge Management Capability. Business Systems Research, 9(1), 1-18. https://doi.org/10.2478/bsrj-2018-0001.

Orfila-Sintes, Francina and Mattsson, Jan (2014). Hotel innovation and its effect on business performance, International Journal of Tourism Research, 16(4), 388-398. https://doi.org/10.1002/jtr.1933. 